\title{
原子力機器材料の開発の歩みと今後の展望 一室蘭から世界へ
}

(株)日本製鋼所 室蘭製作所 佐藤 育男

\begin{abstract}
本稿は日本原子力学会「2006年秋の大会」の記念講演の内容をまとめたものである。「2006年秋 の大会」は北大で開催され，北海道も原子力関連で頑張っているところを紹介するために「室蘭か ら世界へ」というサブタイトルをつけた。

室蘭製作所は，白鳥湾と呼ばれる天然の良港の地に民間最大の兵器会社として，主に砲身と防 弾鋼板を国産化するため，1907年に創業を開始した。写真は，大正10～15年当時に製造された軍 艦用 $41 \mathrm{~cm}$ 榴弾砲の砲身である。終戦後の民需転換に伴い, これらの製造技術が原子力機器用材 料等(特に高品質鍛鋼品)の製造へ受け継がれた。

近年, 世界各国では地球温暖化対策およびクリーンエネルギーとして原子力発電の役割が再評 価され，「原子力ルネッサンス」の声が大きくなってきている。新規原子力発電所建設が始まって いるこの時に, 安全と信頼が不可欠である機器材料の開発の歩みを振り返り, 更なる信頼性向上 へとつなげる材料製造を考えてみたい。
\end{abstract}

\section{I．原子力機器材料の推移と実績}

昭和30年代に日本でも原子力発電導入の機運が高ま り，英国で開発された「コールダーホール型のガス冷却 炉」の採用が日本の第 1 号商業炉として決定した。原子 炉容器の材料は約 $100 \mathrm{~mm}$ の $\mathrm{Mn}$ 鋼で英国/スコットラ ンドで製造されたが，日本での検查で割れ状火陥で不 良」と判断され全数廃却ということになった(日本原子力 学会誌, Vol 33, No.6(1991), 「温故知新」参照)。代品に ついては当所の防弾鋼板の製造実績から資格判定審查を 経て，全数要求品質を満足し製作された。これが当所に とって初めての原子力用材料の取組みであった。この原 子炉は出力 16 万 $\mathrm{kW}$ で，穴の後の原子力発電所の大型 化に伴い，鋼板ばかりでなく，多くの鍜鋼品を世界各国 の原子力発電所向けに納入してきた。第 2 図に原子炉等 1 次系機器用材料 (主に鍛鋼品) の納入実績を示すが, 国 内発電所59基，世界17力国，153基の発電所で使用され るまでに至っている。この図に示すシェアは，当社の製 品が使用されている発電所基数を, 全発電所で割った值 として算出した。

The Course of Development of Material used for Nuclear Steam Supply System Component and the Future Prospect; To the World from Muroran : Ikuo SATO.

(2007年 1 月10日 受理)

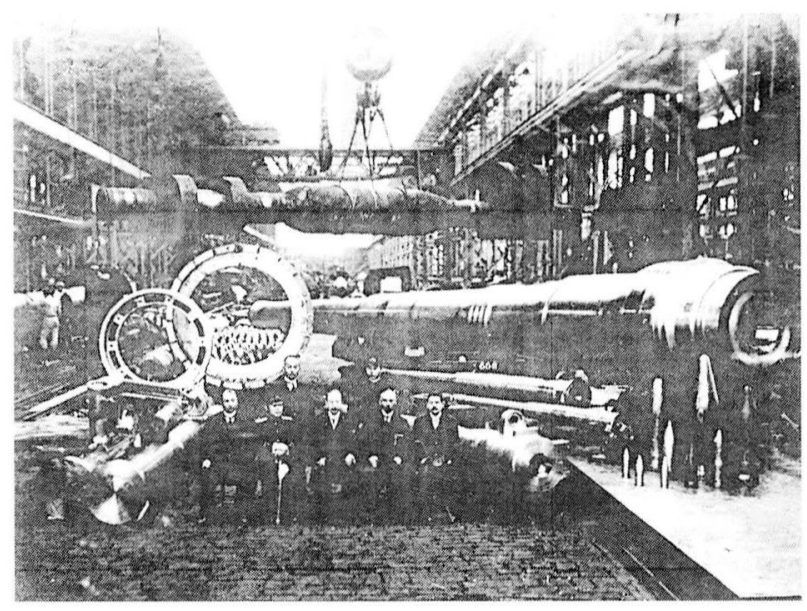

第 1 図 大正 15 年製造の榴弾砲 $\left(410 \mathrm{~mm}^{\Phi} \times 18.450 \mathrm{~mm}^{\mathrm{L}}\right)$

1. 原子力発電所の単基容量の増大と今後の計画 原子力発電所の単基容量は約 40 年の間に急速に巨大化 し, 現在, BWR では改良型 BWR (ABWR) は 135 万 $\mathrm{kW}$, またPWR では EPR (欧州型 PWR)が開発され，160万 $\mathrm{kW}$ までに達してきている。第 3 図に, 発電単基出力と 炬心領域の容器寸法を示す。炉心領域には継目溶接のな い一体鎜鋼リングが採用されてきているが，その径㧍よ び板厚は大きさを増してきている。国内の今後の建設中 および計画中に抒いてもBWRはABWRへ，PWRは 改良型 (APWR)が検討されてきている。

欧州に打いても，フィンランドは EPR を建設中であ り, フランスは EPRの着工を決定した。EPR 用大型フ 


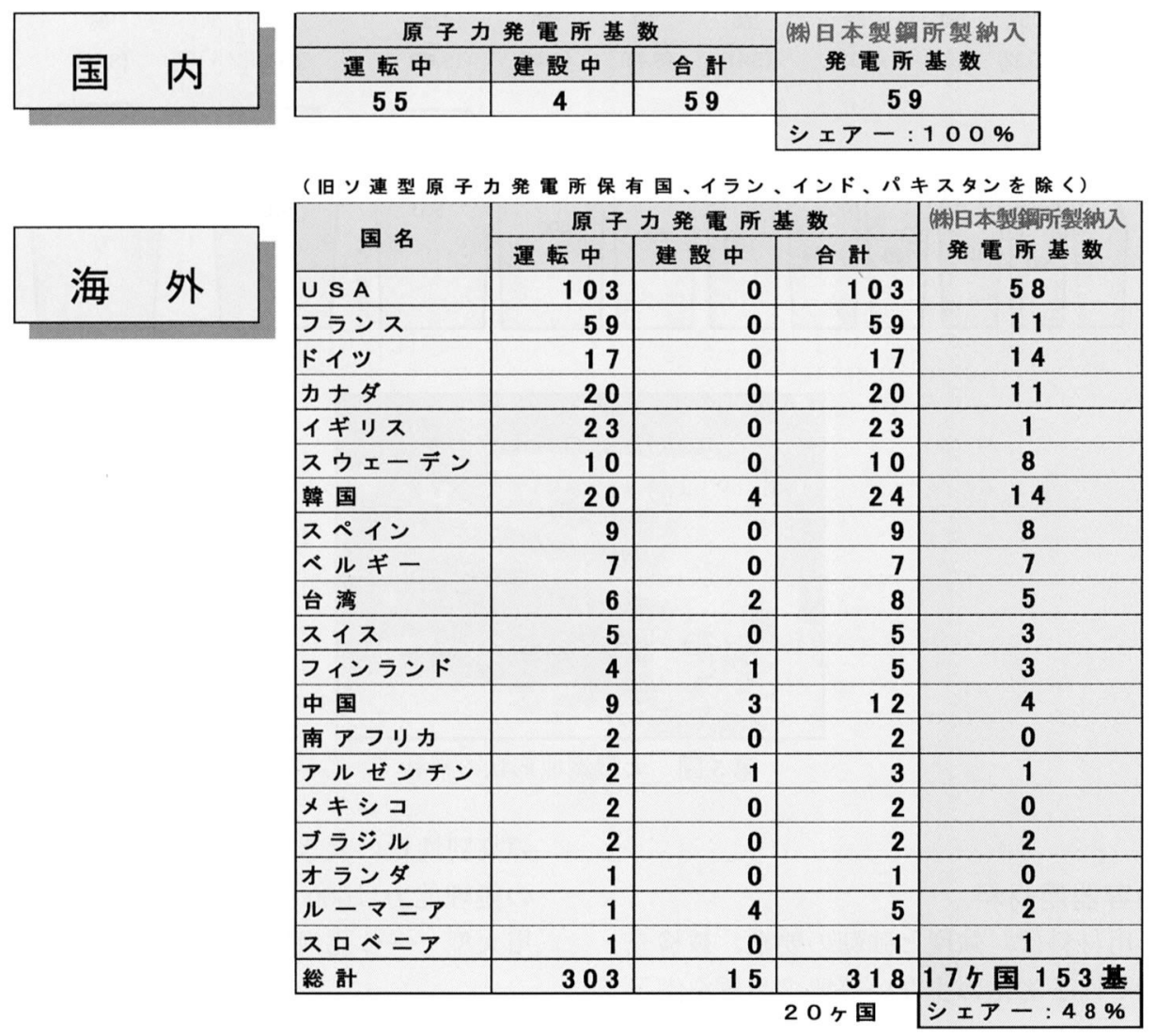

第 2 図 原子炉等 1 次系機器用部材の納入実績 (2006年 8 月現在)

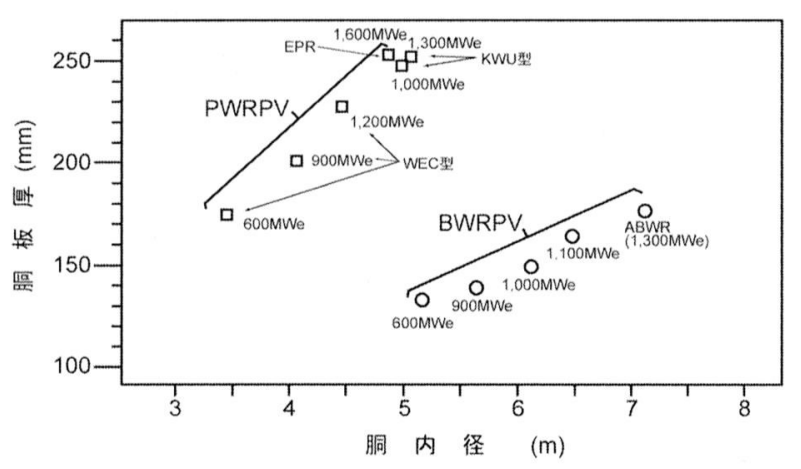

第 3 図 発電出力と原子炉炉心領域の容器寸法の関係

\section{ランジを第 4 図に示す。}

また，米国においても2005年 8 月に包括的エネルギー 法案の可決に伴い, 新規原子力発電所建設計画が出てき ており，2010年着工，2015年運転開始を目標に電力各 社が活動を開始している。炉型としてはABWR, ESBWR，AP-1000，US-EPR 等があげられている。

また，中国においても第2.5世代と呼ばれている100万 $\mathrm{kW}$ クラス (CPR， CNP 型) および第 3 世代と呼ばれて いる AP-1000, EPR等を候補として2020年までの計画 が出されている。原子力ルネッサンスと呼ばれる状況が 具体化されつつある。
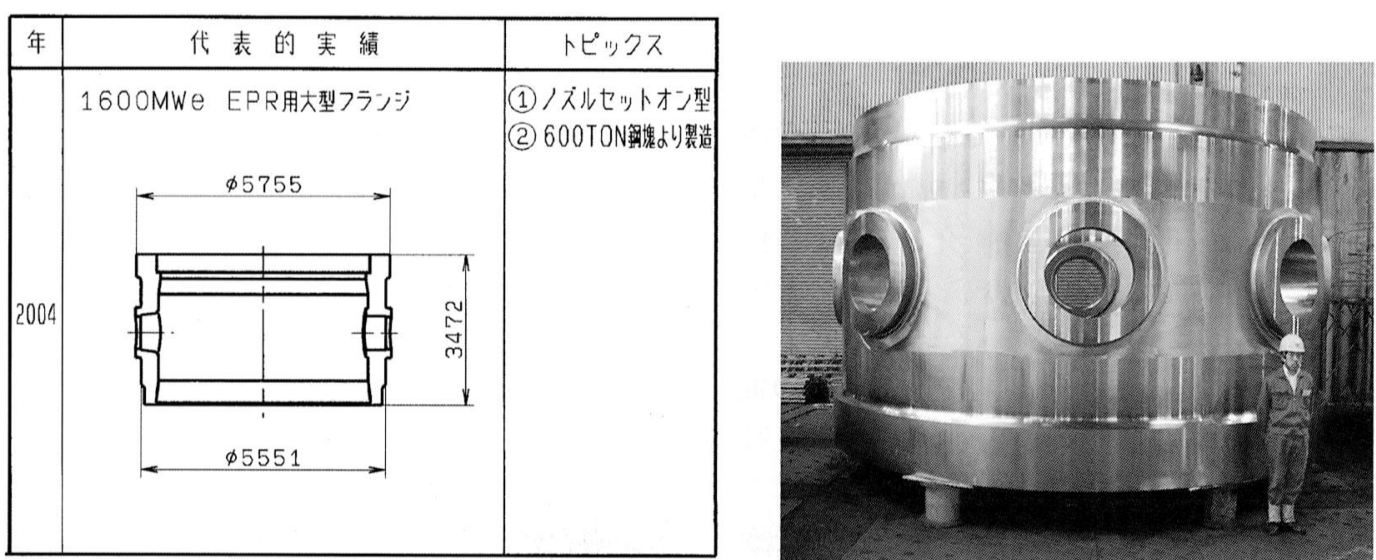

第 4 図 EPR 用 RPV/ノズルシェルフランジ 


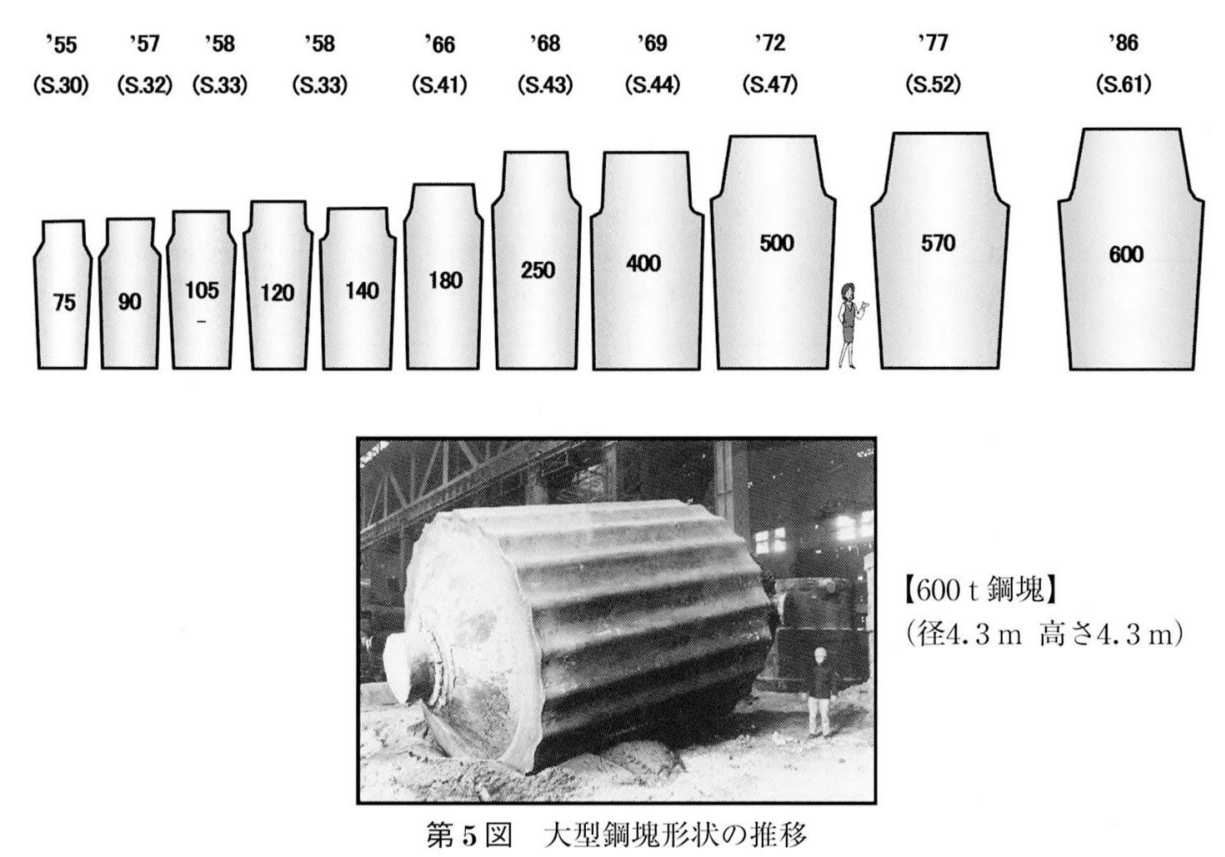

\section{2. 原子炉圧力容器用材料}

原子炉圧力容器用材料は, 強度と強勒の要求, 被検查 性, 溶接性㧍よび中性子劣化の少ない等要求品質を満足 すべく，現在の軽水炉に打いては $\mathrm{Mn}-\mathrm{Mo}-\mathrm{Ni}$ 系低合金 鋼が適用されている。また，単基出力の増大，建設工期 短縮掞よび供用期間中検查 (ISI)の削減という点から, 大型化，長大化，一体化掞よび鍛鋼化への材料開発は重 要である。

大型鍛鋼品を製造するための鋼塊の大きさの推移を第 5 図に示すが，現在は世界最大の $600 \mathrm{t}$ 鋼塊が 2 次系の 一体型低圧ロータシャフト用も含めて多く製造されてい る。

\section{II．大型化，一体化鍛鋼品の製造技術}

前述してきた大型化，一体化を実現するために，高品 質な鍛鋼品の製造技術が開発されてきたが，その一部を 以下に紹介する。

\section{1. 溶解・精錬・造塊技術}

鋼塊内の偏析や空隙の生成は大型化によって凝固時間 が長くなるほど顕著になる。したがって，高品質の大型 鍛鋼品の製造には，不純物元素，非金属介在物などを低 減するとともに，偏析，空隙などの生成を抑制した健全 な鋼塊の製造技術の確立が重要である。

当社は，1980年から取鍋精錬技術を開発し，従来の電 気炉精錬と真空鋳込との組合せによる 2 回精錬，2重脱 ガスを可能にした。第 6 図に，溶解・精錬・造塊技術の 変遷を示す。取鍋精錬技術の適用は，第 7 図に示すよう に極低リン $(\mathrm{P})$ ，低硫黄 $(\mathrm{S})$ をも可能とし，さらに材料
の高勒性化に大きく寄与してきている。現在，取鍋精錬 の処理能力は600 t までに至っており，このことが RPV 用大型・一体化鍛鋼品の開発を成功させている。

\section{2. 鍛造技術}

鍛鍊工程では，鋼塊の凝固組織を高温拡散と塑性変形 を利用して消滅させるとともに，鋼塊内部に形成される 空隙を圧着し，健全な内部性状を得る必要がある。当社 では，1940年に運転を開始した10,000 t水圧プレスを 2003年に14, 000 tプレスにリニューアルし大型鍛鋼品の 需要に備えた。大型 RPV 部材の一部は，プレス内での 鍛鍊は困難な形状にまで大型化したために，1972年にプ レス機外で鍛錬を行う装置が開発された。第 8 図に，プ レス機内および機外䤮錬の状況を示す。この技術によっ て, RPV用リング材の大径鍛鋼品の製造が可能となった。

\section{3. 熱処理技術}

大型鋼材の内部品質と機械的性質は熱間加工後の熱処 理によって大きく左右される。熱処理工程は焼きなら し・焼戻しと燒入れ・焼戻しの 2 段階で行われる。特 に, 焼入れ・焼戻しは所定の強度や勒延性等の機械的性 質の付与を目的とするもので，これらは化学成分や結晶 粒度および冷却速度等の関数として決定される。大型 $\mathrm{RPV}$ 部材の焼入れ・焼戻しは, 径 $9 \mathrm{~m}$, 高さ $6 \mathrm{~m}$ の円 形ガス炬と径 $9 \mathrm{~m}$, 深さ $6 \mathrm{~m}$ の強制循環水装置付き水槽 によって実施される。第 9 図に $\mathrm{ABWR} \cdot \mathrm{RPV}$ 部材/炕心 領域胴の焼入れ状沉を示す。

\section{4. 機械加工技術}

当社は，施盤，横中繰り盤など計100台を超える加工 機械を備えている。大型 RPV 部材は, 径 $8 \mathrm{~m}$ のターン 
( 1979年)

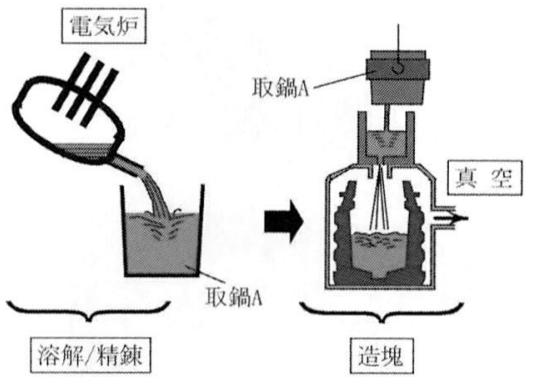

（1980年～）

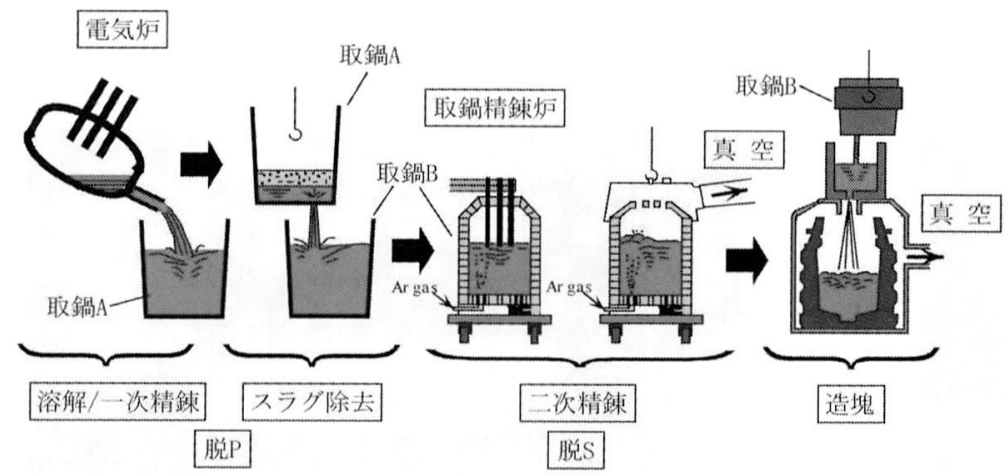

第 6 図 溶解 · 精錬 - 造塊技術の推移
(特徴)

1. 従来技術の特徴

1)電気炉での酸化・還元の連続精錬により リン $(\mathrm{P})$, 硫黄 $(\mathrm{S})$ 成分の低減が困難。

2) 真空処理は鋳込み時の 1 回のみ。

2. 取鍋精錬炬の特徽

1）2回精鍊によるリン (P)、硫黄 $(\mathrm{S})$ の低減 が可能。

2)二重脱ガス (真空処理)による $\left[\mathrm{H}_{2}\right],\left[\mathrm{O}_{2}\right]$ の 低減が可能。

高清浄度鋼の製造が可能

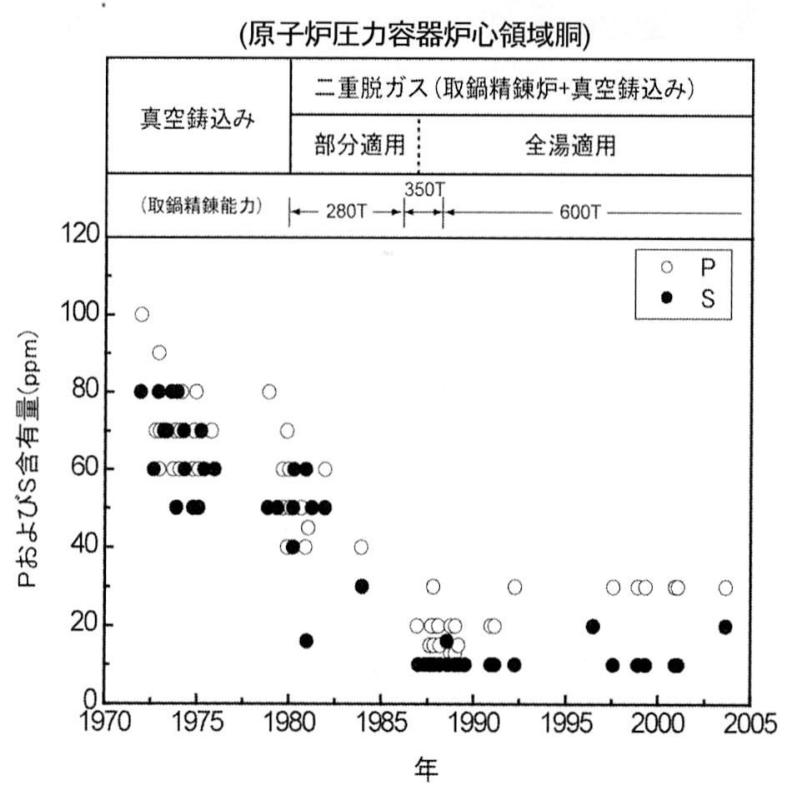

$P:$ 中性子照射脆化元素 $\mathrm{S}:$ 非金属介在物生成元素

第 7 図 不純物 $\mathrm{P}, \mathrm{S}$ 含有量の推移

テーブルを持つ NC 装置付きの超大型堅施盤にて加工さ れる。 $\mathrm{ABWR} \cdot \mathrm{RPV}$ 部材/下鏡ペタルは，内外に10個の ノズルが一体化された製品であり，ノズル間およびノズ ル部の最終加工は NC 加工となる。CAD-CAM 化の採 用により，プログラムの精度および加工精度が向上して いる。第10図に，下鏡リングの機械加工状況を示す。

\section{III. 大型鍛鋼リングの代表的実績}

第11図に大型鍜鋼リングのエポック的な代表実績を示 す。1969年に国産初の敦賀 1 号機向鍛鋼フランジ， 1972 年には西ドイッ PWR 用に, 外径 $5 \mathrm{~m}$ を超える一体鍛造 リングのベッセルフランジが，機外鍜錬法を用いて製造 された。

また，1980年に敦賀 2 号機120万 $\mathrm{kW}$ PWR に一体鍛 鋼リングが採用され，1989年には 110 万W BWR一体 鍛鋼リングが採用，おのおの炉心領域に継目溶接のない 構造となった。

1991年は, ABWR 用鍛鋼リング (ノズル一体型下鏡リ ング)，2004年に EPR 用大型フランジがそれぞれ600 t 鋼塊から製造された。

\section{N. . 今後の展望}

原子力発電も第 3 世代へと進むなかで, 更なる安全性 の追求と供用期間増加を考虑された炉が計画されてい る。また，第 4 世代として高温ガス炉，高速増殖炉，核 融合炬の開発も進められつつある。このような状沉の 中, 高品質な大型化, 一体化鍛鋼品の需要はますます増 加すると思われる。材料メーカーの役割として以下の項 目を精力的に推進し，もの造りの基盤を構貿したい。 


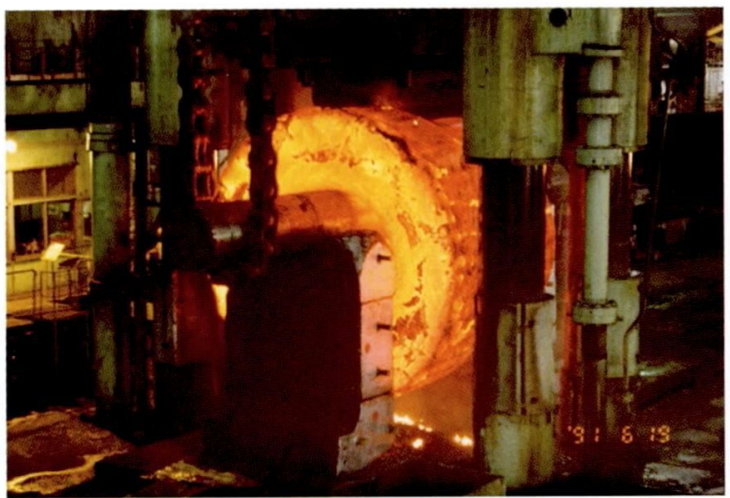

プレス機内鍜錬

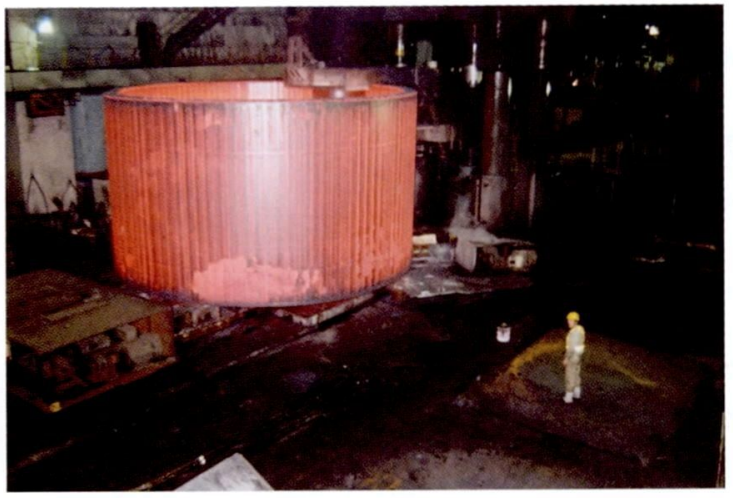

プレス機外鍜錬

第 8 図 プレス機内・機外鍛錬状況

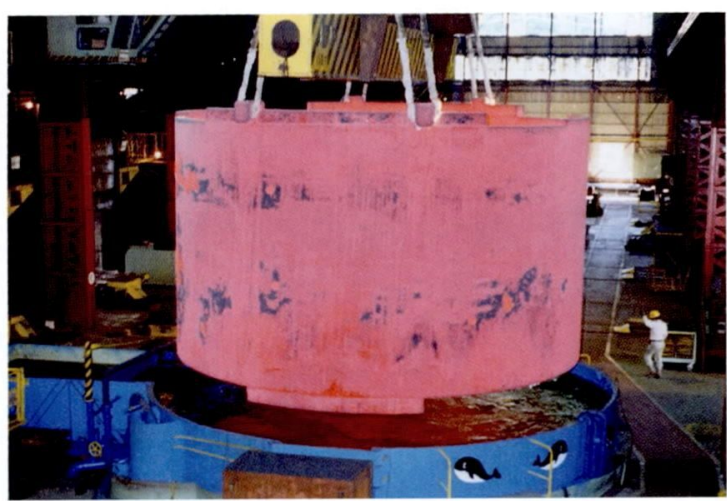

第 9 図 ABWR/炉心領域胴の焼入れ状況

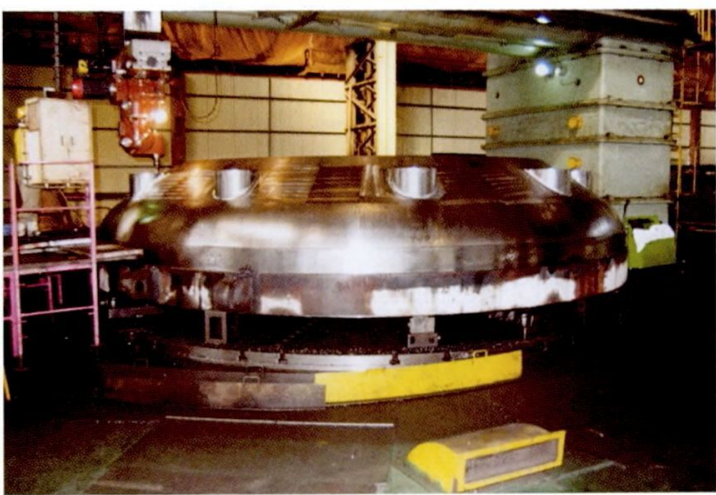

第10図 $\mathrm{ABWR} /$ 下鏡リングの最終機械加工

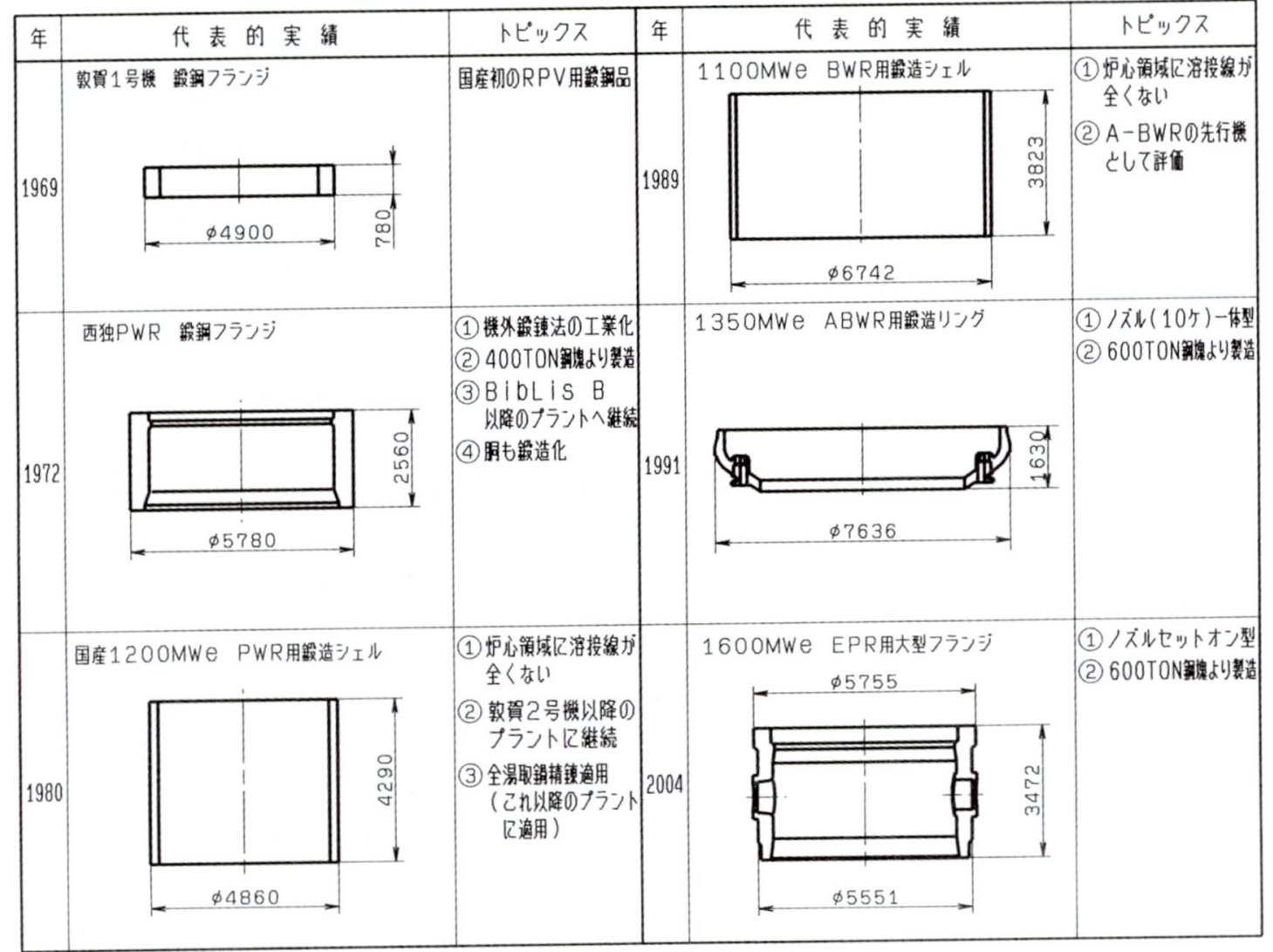

第11図 原子炬圧力容器用大型鍛鋼リング材の代表的実績 


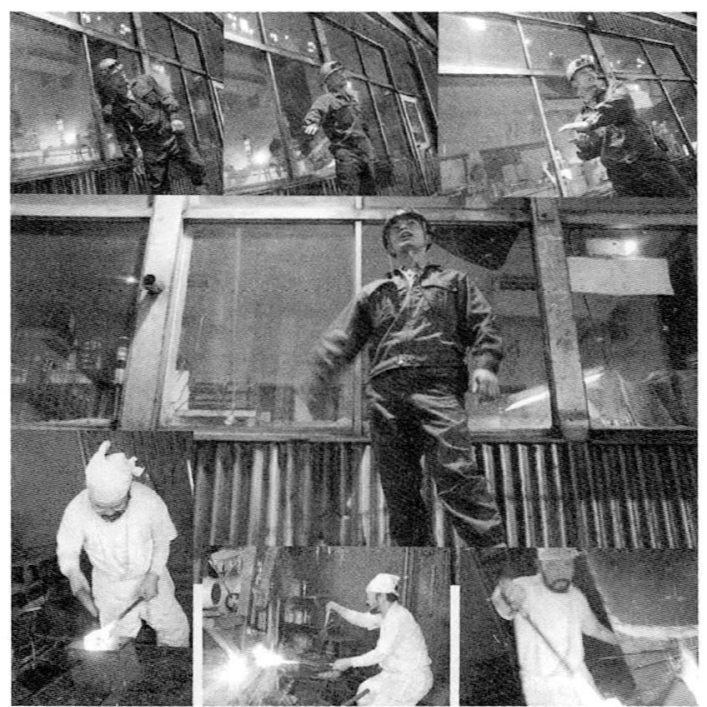

「物づくりの土壤から輩出される人材，そして継承されてき た技術・技能が，最先端の原子炉や発電所の鍛鋼製品を生み 出しているのである。一番大事に継承してきたのが，日本古 来より培われてきた鍜刀技術と，日本人ならではのものづく りのアイデンティティである。これが国際競争力の源となっ ている。

第12図＼cjkstart鍛刀所および鍜錬工場での作業 (物づくり白書 (2005 年版) )
(1) 技術 ·技能の伝承

・物づくりへの「こだわり」と「よろこび」

·技術 No. 1 への追求

・人材の育成, 空洞化 (ワイングラス型, 砂時計型) 対応

・製造実績の継続

(2) 品質保証システムの維持, 向上

·製品品質の確保

・海外規格への取組み

(3) 開発・改善の促進

・材料開発 (高勒性化, 高強度化)

- 新型炉，次世代炬への対応

最後に，2005年版物づくり白書に紹介された鍛刀所と 鍛錬工場を取材した写真と記述を第12図として紹介し， 終わりとする。
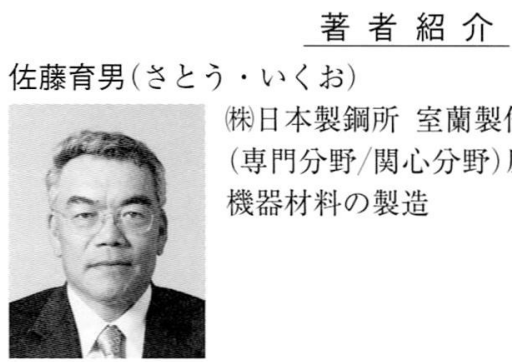

秼日本製鋼所 室蘭製作所

(専門分野/関心分野) 原子力発電所向け主要 機器材料の製造

\section{目安箱への投書}

2005 年 10 月

日本原子力学会編集委員会

編集委員会は，読者・会員・投稿者・査読委員等からのご意見，ご提案を頂き，よりよい学会誌・論文誌編集活動を 目指す心゙く，意見空口「目安箱」を設けております。

・学会誌・論文誌の企画, 編集, 掲載記事・論文に関すること

・論文査読方針・審査方針およびシステムに関すること*

・ 新刊図書の書評の推薦

などについてのご意見・ご要望がございましたら，学会ホームページ http://wwwsoc.nii.ac.jp/aesj/publication/meyasu.html または E-mail（宛先 aesj2005meyasu@aesj.or.jp）にてお寄せ下さい。編集委員会にて検討後，担当編集委員より回答さ せていただきます。

学会誌, 論文誌の編集活動への皆様の積極的なご参加をお願いいたします。

*個々の査読コメント等に関するお問合せ，ご意見等については受け付けかねますのでご了承下さい。 